\title{
Human Resource Management Journal
}

\section{Identification with Management and the Organization as Key Mechanisms in Explaining Employee Reactions to Talent Status}

\begin{tabular}{|c|c|}
\hline Journal: & Human Resource Management Journal \\
\hline Manuscript ID & 19-HRMJ-05395.R2 \\
\hline Wiley - Manuscript type: & Original Article \\
\hline Journal Keywords: & Talent management, Turnover, Career management, Strategic HRM \\
\hline Keywords - Methodological: & Mediation \\
\hline Other Keywords: & social exchange theory, social identity theory \\
\hline Abstract: & $\begin{array}{l}\text { This study examines how identification with management and the } \\
\text { organization explains the relationship between talent status, } \\
\text { organizational citizenship behavior towards the organization (OCB-O) } \\
\text { and the supervisor (OCB-S), and turnover intention. Using archival and } \\
\text { survey data ( } \mathrm{N}=597) \text {, we tested two competing models: a parallel and a } \\
\text { serial mediation. Results supported serial mediation of management } \\
\text { identification through organizational identification; management } \\
\text { identification was the most predictive mediator overall. We also found } \\
\text { different exchange dynamics depending on the focus of the identification } \\
\text { (management or organization) and their corresponding outcomes (OCB- } \\
\mathrm{S} \text { and OCB-O); OCB-S was most strongly related to management } \\
\text { identification. We contribute to the literature by integrating concepts and } \\
\text { assumptions from social identity and social exchange theory, and } \\
\text { advancing the understanding about employee reciprocation of symbolic } \\
\text { resources such as talent status. Practical implications, in particular about } \\
\text { encouraging 'pre-identification' with management in order to ensure } \\
\text { talents' continued extra-role behavior and retention, are spelled out. }\end{array}$ \\
\hline
\end{tabular}

\section{SCHOLARONE Manuscripts}


Identification with Management and the Organization as Key Mechanisms in Explaining Employee Reactions to Talent Status 


\begin{abstract}
This study examines how identification with management and the organization explains the relationship between talent status, organizational citizenship behavior towards the organization (OCB-O) and the supervisor (OCB-S), and turnover intention. Using archival and survey data $(N=597)$, we tested two competing models: a parallel and a serial mediation. Results supported serial mediation of management identification through organizational identification; management identification was the most predictive mediator overall. We also found different exchange dynamics depending on the focus of the identification (management or organization) and their corresponding outcomes (OCB-S and OCB-O); OCB-S was most strongly related to management identification. We contribute to the literature by integrating concepts and assumptions from social identity and social exchange theory, and advancing the understanding about employee reciprocation of symbolic resources such as talent status. Practical implications, in particular about encouraging 'pre-identification' with management in order to ensure talents' continued extra-role behavior and retention, are spelled out.
\end{abstract}

\title{
Keywords
}

Talent management; social exchange theory; social identity theory; identification foci; turnover intention; organizational citizenship behavior 


\section{Practitioner Notes}

What is currently known about the subject

* $60-70 \%$ of organizations have a talent management (TM) program

* TM distinguishes between 'talents' and 'non-talents'

* TM is an exclusive form of employee differentiation

* Social exchange theory explains employee reactions

What this paper adds to existing knowledge

* Social identity mediates the relationship between talent status, OCBs, and turnover intention

* Management identification has direct effects on all outcomes, organizational identification only indirect

* Organizational identification follows from management identification

* Discretionary behavior towards the supervisor is only explained by management identification

The implications of study findings for practitioners

* Being awarded talent status sets in motion psychological processes in employees

* Talent status creates an identification with management prior to promotion

* HR practitioners need to work on tying talents' identification with the organization

* A pitfall is identity struggles among talents 
TALENT STATUS AS SOCIAL IDENTITY -- 1

\section{Identification with Management and the Organization as Key Mechanisms in Explaining Employee Reactions to Talent Status}

Talent management has become a central part of organizations' strategic human resource management practices over the last decade (Collings \& Mellahi, 2009; McDonnell, Collings, Mellahi, \& Schuler, 2017). It is estimated that at least 60 to 70 percent of organizations worldwide have talent management programs in place (Collings, 2015; Silzer \& Church, 2010). Although a variety of definitions exist, talent management commonly denotes activities in organizations that have as their primary purpose to attract, select, develop, and retain high-performing, high-potential employees perceived to have strategic value for longterm organizational success (Collings, Scullion, \& Caligiuri, 2010). These employees—often only 1 to 20 per cent of the organization's population — are then formally awarded 'talent status', meaning that they are formally labeled 'talents' by their organization (De Boeck, Meyers, \& Dries, 2018). As such, talent management is commonly understood as a highly exclusive form of employee differentiation (Dries, 2013; Gelens, Hofmans, Dries, \& Pepermans, 2014). More inclusive forms of talent management—-focusing on the strengths and capabilities of all employees — are also gaining traction both in the academic literature and in organizational practice, but fall beyond the scope of the present article. Interested readers are referred to Meyers and van Woerkom (2014), and Swailes, Downs, and Orr (2014).

In recent years, researchers have become interested in employee reactions to (not) being awarded talent status, as these will largely determine the success or failure of talent management programs (Michaels, Handfield-Jones, \& Axelrod, 2001). A systematic review by De Boeck et al. (2018) found that the dominant theoretical framework used for understanding the dynamics that shape these reactions is social exchange theory- the basic assumption being that employees who are awarded talent status will reciprocate their 
favorable treatment through increased work effort and loyalty (Dries, Forrier, de Vos, \& Pepermans, 2014; Michaels et al., 2001). As De Boeck et al. (2018) conclude, however, social exchange theory alone offers an incomplete understanding of the dynamics that shape employee reactions to talent management. In addition, their review of the empirical literature uncovered unexpected findings, such as 'talents' reporting work alienation in the form of identity struggles (Tansley \& Tietze, 2013).

Therefore, in the present paper, we introduce social identity theory (Tajfel \& Turner, 1979) — specifically, the explanatory mechanism of identification with management and the organization (Horstmeier, Boer, Homan, \& Voelpel, 2017) — as a complementary lens to understanding employee reactions to talent status (De Boeck et al., 2018). Where the key mechanisms in social exchange theory are reciprocity and self-interest, social identity theory allows us to focus on the symbolic and relational consequences of being awarded talent status (Restubog, Hornsey, Bordia, \& Esposo, 2008). That is, talent management practices are not just practices, but also "symbolic carriers of meaning" (De Boeck et al., 2018, p. 210)-they convey identity-relevant information about the extent to which one is valued in the organization. This can lead to employees' identities becoming psychologically intertwined with the organization's identity (Cole \& Bruch, 2006). Rather than being competing theories, however, social exchange theory and social identity theory offer a complementary account of people's reactions to favorable or unfavorable treatment by other parties (Restubog et al., 2008). While the former focuses on the structure and consequences of social interactionsspecifically, how people obtain valued resources from others - the latter focuses on the antecedents of such interactions - most notably, people's need to maintain positive selfrepresentations (Flynn, 2005). The group value model, in particular, offers a framework for studies seeking to integrate both theoretical perspectives. This model states that employee reactions to favorable treatment are not only caused by the rewards or resources themselves, 
but also by what those rewards or resources symbolize (Sousa \& Vala, 2002). It explicitly positions social identity processes as mediating mechanisms between organizational treatment and employee reactions.

The present study investigates how identification with management and the organization contribute to shaping the reactions of employees to being awarded talent status, in terms of organizational citizenship behavior (OCB) and turnover intention. The contribution of this study is threefold. First, it complements existing theorizing in the talent management literature based on social exchange theory by accounting for the symbolic and particularistic 'resources' provided by talent status (De Boeck et al., 2018). Second, it unpacks the exact nature of social identification as a result of being awarded talent status, by disentangling the effects of management and organizational identification respectively. In the literature on identification foci, competing perspective exist on how exactly such different foci relate to each other-i.e., whether they affect outcomes independently or in an embedded (sequential) manner (Horstmeier et al., 2017). In the present study we work with competing hypotheses as to whether management and organizational identification function as parallel or serial mediators, thus contributing to this broader debate (Bartels, Pruyn, De Jong, \& Joustra, 2007). Additionally, we contribute to the talent management literature by introducing a relevant identification target for 'talents' that has so far been neglected (King, 2016) - i.e., identification with the management role, and its specific effects on reciprocation toward one's line manager in the form of supervisor-oriented organizational citizenship behavior (i.e., OCB-S; Rupp and Cropanzano, 2002). Third, the study adds to the limited empirical literature on exactly how talent status relates to turnover intention and OCBs - as empirical studies on such effects have been limited compared to conceptual and proposition papers (Meyers, De Boeck, \& Dries, 2017).

The Role of Social Exchange in Shaping Employee Reactions to Talent Status 
Inherent to the rationale for awarding a small, exclusive group of employees talent status is that this will motivate them to exert discretionary effort (such as OCBs) and stay in the organization (Michaels et al., 2001). So far, most studies have attempted to explain the underlying mechanisms of such effects using social exchange theory (De Boeck et al., 2018). Social exchange theory assumes that employees are largely driven by instrumental concerns associated with 'give and take' between the individual and the organization (Sousa \& Vala, 2002). Employees' actions, then, are understood as determined by the predicted returns they will yield from the organization. Organizational citizenship behaviour and loyalty is thus understood as a reciprocation of the favorable treatment by the organization (cf. the norm of reciprocity), while maximizing the odds of further favorable treatment in the future (cf. selfinterest) (Restubog et al., 2008).

In the talent management literature, it has been proposed that employees awarded talent status are provided with additional resources by the organization, although the resources themselves are rarely specified or operationalized. We know from social exchange theory that resources can be economic (i.e., tangible; addressing financial needs) or socioeconomic (i.e., symbolic; addressing social and esteem needs) in nature (Cropanzano \& Mitchell, 2005). The most often-cited resources associated with talent management are increased organizational investments in talents (e.g., Björkman, Ehrnrooth, Mäkelä, Smale, \& Sumelius, 2013; Gelens, Dries, Hofmans, Pepermans, 2015), career advancement opportunities (e.g., Dries \& Pepermans, 2008; Khoreva \& Vaiman, 2015), and special development practices (e.g., Chami-Malaeb \& Garavan, 2013). It would thus appear that most of the resources considered in the context of talent management are of a tangible nature (Cropanzano \& Mitchell, 2005). However, most of these studies do not actually measure the resources themselves — instead assuming that they are naturally associated with talent status, and that they form the underlying explanatory mechanism in understanding employee 
reactions (Meyers et al., 2017). In addition, although the symbolic nature of talent status has been recognized, it has never been studied empirically (De Boeck et al., 2018). In any case, the literature assumes that 'talents' can be expected to reciprocate whatever resources awarded to them with attitudes and behaviors that are beneficial to the organization, such as increased willingness to improve skills, stronger engagement, and more work effort (De Boeck et al., 2018). In the present paper, we focus on two employee outcomes in particular: organizational citizenship behavior and turnover intention.

Organizational citizenship behavior (OCB) is an "individual behavior that is discretionary, not directly or explicitly recognized by the formal reward system, and in the aggregate promotes the efficient and effective functioning of the organization" (Organ, 1988, p. 4) and represents a highly desirable outcome at work. Studies show that employees who perceive they are provided with good development opportunities show higher levels of OCB towards their workgroup and organization (Kuvaas \& Dysvik, 2009). Discretionary behavior can also be directed towards the immediate supervisor, such as proactively helping him or her. Thus, the literature on OCBs distinguishes between citizenship behavior directed at the organization as a whole (OCB-O) — which has been by far the most studied — and citizenship behavior directed at one's supervisor (OCB-S) (Rupp \& Cropanzano, 2002). OCB-S has been shown to be a construct distinct from OCB-O, and the division has to do with who benefits from the citizen behavior exerted. In OCB-O, the actions primarily benefit the organization. With OCB-S, however, the actions are primarily beneficial for the supervisor (Rupp \& Cropanzano, 2002). To date, there have not yet been any empirical studies explicitly testing the relationship between talent status and OCBs, although several studies have found positive effects on similar variables such as increased work effort (Gelens et al., 2014), motivation for internal career development activities (Swailes \& Blackburn, 2016), and helping the organization achieve its strategic direction (Björkman et al., 2013). 
Turnover intention - defined as "the conscious and deliberate willingness to leave an organization" (Tett \& Meyer, 1993, p. 262)—is typically negatively related to talent status, meaning that talents are less likely to quit (Björkman et al., 2013; De Boeck et al., 2018; McDonnell et al., 2017). There have been some studies that have found higher turnover intentions among talents, however, which they explained by the higher market value and pull for talents, creating power imbalances in favour of the employee — i.e., entitlement — as a result of being awarded talent status (Dries et al., 2014). The dominant rationale is, however, that talent status signals having a good future career in one's organization (Björkman et al., 2013; McDonnell et al., 2017), which cannot necessarily be replicated elsewhere (Dries et al., 2014). In the HR literature more broadly, negative relationships have been found between turnover intention and training investments (Lee \& Bruvold, 2003), as well as recognition and professional development (Paré \& Tremblay, 2007). Based on the above, we thus hypothesize that:

Hypothesis 1. There will be a significant, positive relationship between talent status and (a) $O C B-O$, and (b) $O C B-S$; and a significant, negative relationship between talent status and (c) turnover intention.

As we indicated earlier, however, the focus on instrumentality and self-interest implicit within social exchange theory fails to acknowledge the symbolic and relational consequences of talent management on employees (Restubog et al., 2008). The group value model offers a solution to this tension, as it integrates assumptions from both social exchange theory and social identity theory (Sousa \& Vala, 2002).

\section{Integrating the social exchange and the social identity perspective to understand the}

\section{effects of talent status on employees}

Social identity theory is concerned with how people integrate their belonging to different groups into their self-images, and how they draw self-esteem from these group 


\section{TALENT STATUS AS SOCIAL IDENTITY -- 7}

affiliations (Tajfel \& Turner, 1979). When applied to work settings, this theory helps us understand the symbolic dimensions of organizational practices. The group value model, in particular, states that employee reactions to organizational treatment are mediated by identification of those employees with different groups or levels within the organization (Sousa \& Vala, 2002). Outside of the talent management literature, a number of studies have showed that organizational identification mediates the effects of organizational practices on employees' turnover intention and OCB (Riketta, 2005; van Knippenberg \& Hogg, 2018).

Identification, then, refers to the process through which social identity is formed as a function of (perceived) group membership (Bartels et al., 2007). For instance, employees can attach their self-image to their organization, workgroup, profession, career, and/or supervisor (Ashforth, Harrison, \& Corley, 2008). Two previous studies have found a positive relationship between talent status and identification with different groups in the organization: Björkman et al. (2013) on identification with the focal unit, as well as with the MNE (multinational enterprise) as a whole; and Khoreva and van Zalk (2016) on organizational identification. Such different identification targets are also known as 'foci' of identification (Millward \& Haslam, 2013). In the present study, we argue that two foci are central to understanding the social identity processes associated with talent status: identification with the organization, and identification with management.

Talent status and organizational identification. Although there has not yet been a lot of empirical research on talent status and organizational identification (Björkman et al., 2013; Khoreva and van Zalk, 2016), we can assume a positive relationship between both based on insights from related literatures. Flynn (2005) found that there is a cyclical relationship between employees' identity orientations (i.e., who they identify with) and their patterns of social exchange (i.e., whom they choose to cooperate with). Specifically, the literature has described three types of identity orientations - i.e., personal, relational, and collective - that 
all relate to a different pattern of exchange (Brewer \& Gardner, 1996). Those with a personal identity orientation tend to engage in short-term transactional exchanges informed by selfinterest; a relational orientation is typically characterized by direct reciprocation between two or more exchange partners; and a collective orientation is associated with 'generalized exchange', meaning that employees will aim to do good for the organization as a whole. At this point, reciprocation is no longer a suitable construct for understanding the terms of the exchange relationship — rather, the key mechanism becomes social identity (Flynn, 2005).

Empirical research indeed found that the more salient a social identity is, the more committed employees will feel to it, and the more they will exhibit behavior consistent with the identity (Stets \& Burke, 2003). We thus propose that talent status creates a highly salient attachment, which, due to its organization-specific nature (Dries et al., 2014) will enhance these employees' identification with the organization. That is, by awarding an employee talent status, the organization ascribes high status and positive regard to him or her, which causes the organization to become a dependable source for security and self-esteem for that employee (Björkman et al., 2013). We can expect this to set off a positive cycle of increased OCB-O, OCB-S, and lowered turnover intentions which in turn again reinforce and strengthen the organizational identification (Flynn, 2005). Ibarra (2005), for instance, stated that "extrarole behaviors are important ways of asserting one's work identity" (p. 12).

The relationship between organizational identification, OCBs, and turnover intention is well-established (Lee, Park, \& Koo, 2015). There is robust support for the causal relationship between organizational identification and OCB-O (Van Dick, Grojean, Christ, \& Wieseke, 2006). It has also been found that employees who identify with their organization are more likely to help their supervisor, since he or she is a representative of the organization (Fuller, Hester, Barnett, Frey, Relyea, \& Beu, 2006). Hence, it is likely that organizational identification will not only relate to higher OCB-O, but also higher OCB-S. Finally, previous 
research established that organizational identification decreases employee turnover intention (Cole \& Bruch, 2006; van Dick, Wagner, Stellmacher, \& Christ, 2004). We thus hypothesize that:

\section{Hypothesis 2. Organizational identification will mediate the relationship between talent} status and (a) OCB-O, (b) OCB-S, and (c) turnover intention.

Talent status and management identification. One specific characteristic of talent status that has so far been neglected in the literature is that it enhances the likelihood that employees will start self-identify with management. As stated in social identity theory, the categorization of oneself as a member of a certain group does not require formal inclusion into that group — rather, it suffices that the individual is made aware of an important similarity between him- or herself and the group in question (Tajfel \& Turner, 1979). Although conceptually, being 'talented' refers to excelling in any given domain — of which management is only one (Meyers \& van Woerkom, 2014) - in practice we see that talent status is often equated to being seen as a future leader in one's organization (Silzer \& Church, 2010). Talent status thus signals that the employee is expected to advance within the organization hierarchically and take up progressively more complex tasks and roles (Björkman et al., 2013; Collings \& Mellahi, 2009). In many organizations, this implies starting to prepare for more managerial responsibility (Gallardo-Gallardo \& Thunnissen, 2016) or a more important role. Even before any particular position has been granted to the individual, it is thus possible that he or she starts thinking about him- or herself as a (future) member of management. Indeed, 'us versus them' thinking is a critical aspect of social identity theory, as identity is just as much a function of who we are similar to versus who we are distinct from (Cole \& Bruch, 2006). As is reflected in the items of management identification (Mael \& Ashforth, 1992), it is likely that talent status encourages talents to think of management as 'we', whereas their 
coworkers who were not awarded talent status - who are just as much non-members of management as the talents are-are more likely to think of management as 'them'.

Ibarra's (2005) concept of liminal (i.e., 'in-between') identity seems of particular relevance here. She theorized that prior to a career transition, employees' self-images start to shift well before they actually enter into a new role, as a gradual process of preparation. She referred to this process as anticipatory socialization, and indicated that especially internal role transitions tend to have blurred boundaries, as it is often ambiguous when exactly they will occur. This uncertainty causes employees to look to reference groups for identity cues.

Based on this reasoning, we expect 'talents' to report higher management identification, and in turn higher OCB-O and OCB-S. This is because management identification instills a willingness in employees to act responsibly and proactively, and not just focus on what is strictly required of them (cf. OCB-O) - hallmarks of the managerial role. Furthermore, management identification is likely to associate with an increased willingness to help those in managerial positions, most notably one's direct supervisor (cf. OCB-S). Finally, if employees want to maintain the positive self-image they derive from membership in this group, they will have to stay within the organization. In other words, management identification is expected to mediate the relationship between talent status and turnover intention, as well:

Hypothesis 3. Management identification will mediate the relationship between talent status and (a) OCB-O, (b) OCB-S, and (c) turnover intention.

\section{Identification with Management vs. the Organization: Parallel or Serial Mediators?}

Examining two identification foci in the same study calls for a theorization of how these two foci relate to one another - an issue that has been recently debated in the literature on organizational identification (Horstmeier et al., 2017). A first line of reasoning refers to the so-called correspondence of focus principle, which states that identification with a certain unit in working life will be most strongly related to outcomes at the same level of abstraction- 
i.e., organizational identification should be related to outcomes that clearly have to do with the organization, identification with one's team should relate to team outcomes, and so forth (Riketta \& van Dick, 2005; van Dick, Wagner, Stellmacher, \& Christ, 2004). The rationale is that employees will most strongly identify with the organizational entities 'closest' to them, i.e., the ones that they interact with on a day-to-day basis (Restubog et al., 2008). These might include the own team, one's supervisor, one's department, etc. Further, the assumption is that identification with a certain focus will also translate into an increased propensity to act in ways that will benefit this focus in particular (Bartels et al., 2007). A meta-analysis by Riketta and Van Dick (2005) found that associations between identification and outcome variables are indeed stronger when identification foci outcomes match than when they do not (i.e., work group identification with team-level outcomes such as team climate perceptions, organizational identification with organizational-level outcomes such as intention to quit).

This line of reasoning implies parallel mediation: Management identification and organizational identification should relate in differing degrees to the outcomes under study, depending on their correspondence to the focus. Specifically, management identification should mediate the relationship between talent status and OCB-S, since this outcome concerns the person that personifies the management function for employees (i.e., the supervisor). For the same reason, organizational identification should mediate the relationship between talent status on the one hand and OCB-O and turnover intention on the other, given that these outcomes are most closely related to the organization.

\section{Hypothesis 4.1. Management identification and organizational identification are} parallel mediators of the relationship between talent status, OCBs, and turnover intention, such that management identification is most strongly related to $O C B-S$ and organizational identification to OCB-O and turnover intention. 
A competing logic, however, is that different identification foci are hierarchically nested within each other, and that when management identification is high, organizational identification will also be (Bartels et al., 2007). The rationale is that management are seen as human agents of 'the organization', the latter being an abstract entity that requires anthropomorphization in order to identify with it (Cole \& Bruch, 2006). This school of thought distinguishes between lower-order entities that are more local and visible, and higherorder entities that are more distant and abstract, and propose that lower-order identifications form the basis of identification with the organization as a whole (Ashforth \& Johnson, 2001). Bartels et al., (2007) found, for instance, that the more an employee identifies with a certain level in the organization, the more he or she also identifies with other organizational levels. In the same vein, Marique and Stinglhamber (2011) found that the relationships between occupational and workgroup identification and affective organizational commitment were mediated by organizational identification.

This line of reasoning thus implies serial mediation. That is, it implies that in order for management identification to lead to employee outcomes, it first needs to translate into organizational identification. Even OCB-S, which is an outcome closely corresponding to management, would then not directly be related to management identification, but through the mechanism of organizational identification.

Hypothesis 4.2. Management identification and organizational identification are serial mediators of the relationship between talent status, OCBs, and turnover intention, such that organizational identification mediates the relationship between management identification, OCBs, and turnover intention.

\section{Method}

\section{Participants and procedure}


Survey data were collected from 597 employees from a large Swedish public-sector organization (representing a 48\% response rate), which had publicly and transparently implemented a formal, exclusive talent management program six months prior to the start of the study, for the first time in its existence. This made talent status a salient phenomenon at the time of data collection and also lent credence to our assumption that talent status was a key variable in explaining differences in OCBs and turnover intention in this sample. Furthermore, a transparent context is rare to find in field research on talent management (Sumelius, Smale, \& Yamao, 2020). This allowed us to use archival data rather than selfreport for the talent status variable, which is a key recommendation for doing research on employee reactions (De Boeck et al., 2018).

'Talent' was defined by the organization as having excellent performance as well as the potential to take on more complex tasks in the future. Being awarded talent status did not imply new formal work tasks, but talents were expected to take more initiative and be willing to take on additional key projects. Furthermore, talents would be first considered when opportunities for interesting new positions or assignments became available. All employees knew whether they had been identified as talents or not - this information was given to them individually in the annual development talk that they had with their unit manager. All talks were held over the course of one month, six months prior to data collection. Knowledge of colleagues' talent status was also fairly widespread, although the full list was not communicated publicly_all formal communication was done at the individual level.

An survey was distributed online to 1,256 employees. According to archival data obtained from the HR department, 151 of these were formally identified as talents and 1,105 were not. Valid responses were collected from 597 employees (105 talents and 492 nontalents, representing a response rate of $70 \%$ and $45 \%$, respectively). The sample contained 491 women and 106 men. The youngest participant was 24 years old and the oldest $68.14 .5 \%$ 
of respondents worked in the organization for one year or less and $8 \%$ for 22 years or more. None of the respondents held supervisory or leadership positions. Means and standard deviations are reported in Table 1.

\section{Measures}

Independent variable. Talent status $(0 / 1)$ was provided by the organization for each respondent based on archival data.

Mediators and dependent variables. Items were translated into Swedish with Brislin's (1986) back-translation procedure used to verify the quality of the translation. All items were rated on a seven-point Likert scale $(1=$ Strongly disagree, $7=$ Strongly agree $)$. Organizational identification was measured with four items from Mael and Ashforth's (1992) scale, a sample item being “When someone praises [organization's name], it feels like a personal compliment ( $\alpha=$.76). Management identification was measured using the same four items but adapted to management function, for example "When I talk about management, I usually say 'we' rather than 'they' " $(\alpha=.81)$. Literature supports such adaptation to apply the scale to different identification foci (e.g., Bartels, Pruyn, De Jong, \& Joustra, 2007; Millward \& Haslam, 2013). OCB-organization (OCB-O) was assessed with five items from Lee and Allen (2002), for example "I act to protect [organization's name] from potential problems" ( $\alpha$ $=.84$ ). OCB-supervisor (OCB-S) was measured with three items from Rupp and Cropanzano (2002), a sample item being "I help my supervisor when he/she has a heavy workload" ( $\alpha$ $=.92$ ). Turnover intention was measured with three items from Khatri, Fern, and Budhwar (2001), for example "I will probably look for a new job in the next year" $(\alpha=.92)$.

Control variables. We controlled for age, gender, and organizational tenure as these variables could affect both organizational identification dynamics as well as OCBs and turnover intention. 
Analyses. Before testing the hypotheses, the quality of the data was checked. In order to determine the validity of the measurement model, confirmatory factor analysis (CFA) was performed using the AMOS software. The measurement model showed satisfactory fit $\left(\chi^{2}=\right.$ $481 ; d f=141 ; \mathrm{GFI}=.92 ; \mathrm{CFI}=.95 ; \mathrm{RMSEA}=.06 ; \mathrm{SRMR}=.06)$. To check convergent and discriminant validity of the measures, a series of alternative measurement models, combining the constructs in various ways, was tested and further analyses were performed. The results showed that none of the tested measurement models produced better fit than the original one. Unlike the independent variable that was documented six months prior to the study, the mediators and dependent variables were self-report and collected simultaneously. Although design remedies were applied (i.e., respondents were assured of the anonymity and confidentiality of the responses; questions were separated in the questionnaire), we applied a statistical approach to investigate the extent of any potential common method bias. Following the recommendation by Podsakoff, MacKenzie, Lee, and Podsakoff (2003), a latent factor was added to the measurement model. All items were allowed to load on this factor while simultaneously loading on their respective constructs. The results showed that item loadings remained statistically significant on their respective constructs even after adding the latent factor, suggesting common method bias is not a concern in the study. To test our hypotheses, mediation analysis (parallel and serial) as proposed by Hayes (2018) was used. All analyses were performed using PROCESS procedure (confidence interval for the indirect effect is based on 5,000 bootstrap samples).

\section{Results}

Table 1 shows the descriptive statistics and intercorrelations of our study variables. In comparison to non-talents, talents had longer tenure, expressed stronger identification with management and organization, and scored higher on OCB-S and OCB-O $(p<.05)$. Hypotheses la and $1 \mathrm{~b}$ specified that talent status would be positively related to OCB-O and OCB-S, 
respectively, whereas Hypothesis 1c stated that talent status would relate negatively to turnover intention. The relationship between talent status and OCB-O and OCB-S was indeed positive and statistically significant $(b=.23$ and $.57, p<.05$, for OCB-O and OCB-S, respectively). Thus, Hypotheses 1a and $1 \mathrm{~b}$ were supported. The relationship between talent status and turnover intention was weak and not statistically significant $(b=.06, p>.05)$. Hypothesis 1c was thus not supported.

-- Insert Tables 1 and 2 about here --

In Table 2 we can see that identification with management had a statistically significant direct relationship $(p<.01)$ with OCB-O, OCB-S, and turnover intention $(b=.14$, .74 , and -.14 , respectively), even after controlling for talent status. Organizational identification also had a direct relationship $(p<.01)$ with OCB-O and turnover intention $(b=$ .64 and -.56 , respectively). The regression coefficients of the direct relationship between talent status and OCB-O $(b=.10, p<.10)$ and OCB-S $(b=.38, p<.01)$ was smaller than the regression coefficients of the total relationships. For turnover intention, the direct relationship $(b=.24, p>.05)$ was larger than the total relationship $(b=.06, p>.05)$. These changes suggest mediation dynamics (MacKinnon, Krull, \& Lockwood, 2000).

--Insert Table 3 about here--

Table 3 and Figure 1 present results for testing our parallel and serial mediation hypotheses. Hypotheses 2a-c and Hypotheses 3a-c state that the two identification forms independently mediate talent status relationships with the three outcome variables. Figure 1 shows $a_{1}$ coefficient and three $b_{1}$ coefficients (management identification is mediator) and $a_{2}$ coefficient and three $b_{2}$ coefficients (organizational identification is mediator). Parallel mediation analyses show that for management identification all indirect relationships $\left(a_{1} b_{1}\right.$ for each of the three outcomes) have zero-free confidence intervals. For organizational 
identification $\left(a_{2} b_{2}\right)$, the three confidence intervals include a zero. Thus, we find support for Hypotheses 3a-c but not for Hypotheses 2a-c.

--Insert Figure 1 about here--

The results of our parallel vs. serial mediation models (competing Hypotheses 4.1. and 4.2.; Table 3) indicate that for OCB-O, the indirect relationship was significantly positive, suggesting that talents reported higher management identification (positive $a_{1}$ ) which in turn was associated with a stronger organizational identification (positive $d_{21}$ ), which in turn translated into higher OCB-O (positive $\mathrm{b}_{2}$ ). The indirect serial relationship between talent status and OCB-S was not significant. Although identified talents reported higher management identification (positive $\mathrm{a}_{1}$ ) and this was associated with higher organizational identification (positive $\mathrm{d}_{21}$ ), we found no support that this was translated into higher OCB-S ( $b_{2}$ is not statistically significant). This suggests that talents' identification with management is most important for explaining their OCB-S. Finally, for turnover intention, the serial relationship was statistically significant and negative. Talent status was associated with stronger management identification which in turn enhanced organizational identification (paths $\mathrm{a}_{1}$ and $\mathrm{d}_{21}$ are positive), and it was this strong identification with the organization that was associated with lower turnover intention $\left(b_{2}\right.$ is negative). The three indirect serial relationships were statistically significant (Table 4).

-- Insert Table 4 about here--

Finally, it can be noticed from Table 4 that the total relationship between talent status and turnover intention was weak and not statistically significant $(b=.06, p>.05)$. As the reader noticed, the lack of support for Hypothesis 1c did not stop us from empirically testing mediation in this study. As argued by Hayes (2018, p. 80), the precondition for the simple mediation approach that X should be related to Y represents a "misguided and outdated" thinking. Bollen's perspective that "correlation is neither a necessary nor a sufficient 
condition of causality" and "lack of correlation does not disprove causation" (Bollen, 1989, p. 52) has been adopted by leading organizational methodologists (see for instance Preacher, 2015; Rucker, Preacher, Tormala, \& Petty, 2011). Although the direct relationship was positive $(b=.24, p>.05)$, the indirect relationship was negative $(b=-.18, p<.05)$, implying that both cancelled each other out.

\section{Discussion}

The current study aimed to contribute to uncovering the identity-related processes that shape employee reactions to talent status, thus better accounting for the symbolic nature of much of the 'resources' exchanged in talent management. In so doing it responds to recent calls in the literature to investigate mechanisms that cannot be fully understood by social exchange theory (De Boeck et al., 2018). Specifically, we examined the role of two different foci of identification in explaining the relationships between talent status on the one hand, and OCB towards the organization and the supervisor, and turnover intention on the other.

\section{Theoretical Implications}

Our finding that management identification and organizational identification are serial mediators of the relationship between talent status, OCB-O, and turnover intention adds to the scarce research on the interrelationships between different identification foci (Ashforth et al., 2008; Horstmeier et al., 2017). Although identification with management has not received a lot of research attention, our results are in line with prior studies that found that organizational identification mediates the effects of more narrow identification foci (Marique \& Stinglhamber, 2011). In addition, our results show that in contrast to management identification, organizational identification alone was not able to explain the indirect relationships between talent status, OCBs and turnover intention. This suggests that organizational identification may only have an auxiliary, yet important, function in explaining the relationship between talent status and employee outcomes, while management 
identification is a key mediator. In this sense, our findings nicely complement Björkman et al. (2013) and Khoreva and van Zalk's (2016) studies on department- and organizational-level identification of employees awarded talent status.

Interestingly, organizational identification did not mediate management identification in the relationship between talent status and OCB-S. Instead, this indirect relationship ran only through management identification. Theoretically, this finding can be explained using the correspondence of focus principle (van Dick et al., 2004), which states that identification with an entity at a specific level of the organization will most strongly affect outcomes at that same level (Ellemers \& Rink, 2005). Overall, our findings suggest that identification with management is an important, but neglected mechanism in understanding employee reactions to talent status. This finding is important for gaining a better theoretical understanding of talent status, by reframing it as a liminal (i.e., 'in-between') space within which social identities are formed, meaning that although 'talents' are not yet managers they can be expected to identify with management as a form of anticipatory socialization (Ibarra, 2005).

The positive relationships between talent status on the one hand and OCB towards the organization and supervisor on the other are in line with previous studies linking talent status to favorable attitudinal outcomes (e.g., Björkman et al., 2013; Khoreva \& van Zalk, 2016). The finding that talent status is associated with exerting discretionary effort targeting both one's employing organization as a whole and one's supervisor strengthens the assumption that talent management can create a favorable impact on employee attitudes and behaviors.

For turnover intention we found a positive, although not statistically significant relationship with talent status. The mediation analysis, however, uncovered significant indirect relationships between talent status and turnover intention, in the opposite direction. Mathematically, opposing relationships in mediation — direct positive (associating with greater turnover intention) and indirect negative (associating with lower turnover through 
management and organizational identifications, respectively) — cancel each other out (McKinnon et al., 2000). Practically, this suggests that talent status simultaneously has positive and negative effects. One explanation for the positive direct effect - already raised in previous studies finding higher turnover intentions among talents - could be that talent status makes an employee more aware of his or her attractiveness on the job market (Dries et al., 2014). As the findings from the present study suggest, however, identifying with management and one's organization has the potential to counteract such 'pull' factors. This finding is quite insightful as it does not only add to the scant research on the possible effects of talent management on retention, but also suggests that awarding talent status can have undesirable side-effects for organizations. Our finding of simultaneous positive and negative relationships also helps explain some of the contradictory findings reported in previous research on employee reactions to talent management (Björkman et al., 2013; Dries \& Pepermans, 2007; Gelens et al., 2014). That is, as simultaneously positive and negative relationships mathematically cancel out the total effect, our study provides a possible explanation for what may have been interpreted as a 'zero-relationship' between talent status and turnover intention in previous studies.

\section{Practical Implications}

For managers and HR practitioners, the present study points to the importance of considering how talent management might affect employees' identities. It extends previous research by showing how identification with management, specifically, is an important mechanism in the relationship between talent management and desired employee outcomes. In particular, organizations should encourage talents' 'pre-identification' with the management function in order to ensure their continued extra-role behavior and retention (Björkman et al., 2013; Khoreva and van Zalk, 2016). Our conclusion that talent status triggers an in-between identity that one is no longer 'just' an employee, without having to 
immediately promote high-potential employees into management roles, has interesting implications for training and socialization (Ibarra, 2005). Talent management seems to have the potential to make a select group of employees perceive themselves as managerial representatives without having been granted any formal managerial role or responsibilities yet. Organizations could draw on management and organizational identification to counteract the potentially higher turnover intentions of talents driven by their market value (Dries et al., 2014). Retention of talents is a key objective of most talent management programs (Collings \& Mellahi, 2009).

Identification with management could be strengthened through stretch assignments where talents are given informal managerial responsibility early on (Gallardo-Gallardo \& Thunnissen, 2016). Additionally, organizations could increase the amount of interaction between talents and members of management, since research has shown that more frequent patterns of exchange can change employees' identity orientations, leading in turn to more collective exchange patterns on their side (Flynn, 2005). A final idea is to use the terminology of 'management' in a salient and explicit manner in communication about the talent management program, to enhance its identity-related message (De Boeck et al., 2018).

A few words of caution also apply. First of all, previous (qualitative) studies have found that being awarded talent status can lead to so-called identity struggles when employees feel inauthentic or forced to play a role (Tansley \& Tietze, 2013; Meyers et al., 2017). Organizations should be wary of talent management practices that do not align with talents' views of themselves, since these may be less effective or cause psychological issues at work. Second, an open question remains as to the social identity effects one could expect talent management to have on employees not awarded talent status by their organizations - the majority of the workforce (De Boeck et al., 2018). If being awarded talent status makes employees feel valued and included in the organization's in-group, one can only imagine what 
the effects would be on so-called 'non-talents' (Meyers \& van Woerkom, 2014). Our findings indicate that non-talents score lower on social identities OCB-S, and OCB-O. Conceptual work on hybrid inclusive-exclusive talent management approaches may offer a path forward for designing talent management programs that can still be exclusive, but not experienced as exclusionary (Swailes et al., 2014).

\section{Limitations and Avenues for Further Research}

As is the case for all single-standing studies, the present study had some limitations. First of all, although archival data were used for our independent variable (talent status), mediators and dependent variables were measured using cross-sectional self-report data. We did adhere to design recommendations for running cross-sectional studies, and also tested for common method bias statistically (Podsakoff et al., 2003), and found that it did not seem to affect our measurement model. Nonetheless, longitudinal or cross-lagged studies are clearly preferable for most types of research questions relating to employee reactions to talent management, where data access and research infrastructure resources allow researchers to do so. De Boeck et al.'s (2018) systematic review, however, found that there have hardly been any empirical studies to date that have been able to collect data on talent management at multiple points in time. Especially intervention studies with pre- and post-measures are lacking. Although with our design we cannot definitively rule out reverse causality—for instance that employees displaying more OCBs were more likely to be awarded talent status - we feel strengthened in our theoretical assumptions by the fact that our data collection occurred six months after the public and transparent introduction of an exclusive talent management program in our case organization. We thus believe that talent status, or the lack thereof, was a salient variable in employees' response behavior at the time of survey administration. That said, even theoretically the relationship between talent status and identification with management and the organization is believed to be cyclical—employees' 
social identities affect their efforts, which yield organizational rewards, which further strengthen organizational identification, and so forth (Flynn, 2005). In that sense, our findings are not so much threatened by reverse causality as they are explained by cyclical causality (Ibarra, 2005; Stets \& Burke, 2003).

Second, the Swedish public sector setting may have affected the generalizability of our findings with its specific organizational and cultural norms. For instance, the atypical transparency of talent status could reinforce differences between talents and non-talents. Also, the fact that the talent status was given to a fairly large proportion of employees could somewhat decrease its perceived value. Moreover, considering that talent status tends to be awarded primarily to younger employees with shorter tenure it was surprising to find that the employees selected as talents in the current study displayed a longer average tenure in the organization than non-talents. That said, we do believe more studies on talent management are needed in settings other than large, for-profit multinational companies. Although several conceptual and proposition papers assume, for instance, that organizations in the public and governmental sector will opt for more inclusive practices due to institutional pressures (Swailes et al., 2014) and transparency obligation, little empirical evidence exists to support this claim. In fact, studies on this issue suggest that public-sector organizations look to best practices from the private sector to develop their talent management programs, such that they end up being equally exclusive and 'hard' (Thunnissen \& Buttiens, 2017).

Third, this study did not account for the potential discrepancy between respondents' self-perceived talent status and the actual status awarded by the organization - a phenomenon that is estimated to be common in the field (Sonnenberg, van Zijderveld, \& Brinks, 2014). We argue that (although interesting) this is not a 'limitation' of the current study per se, however. That is, all employees that were surveyed were fully aware of their (non-)talent status as awarded by the organization. Therefore the issue of talent status awareness vs. ambiguity 
(where self-perceived and formal status are compared empirically to assess the extent to which people report the correct talent status; see Sonnenberg et al., 2014; Ehrnrooth, Björkman, Mäkelä, Smale, Sumelius, \& Taimitarha, 2018) was less relevant in the present study than perhaps in others. As our measure of talent status was archival, and all employees were personally informed of their status, in our study it was safe to assume perfect alignment between archival and self-reported talent status. The question of whether people agree with their talent status is also an interesting and important one, but answering it would require an entirely different theoretical framework. From a social identity perspective, talent status could never be ascribed by an individual to themselves, as it defines status as an individual's consensually acknowledged social worth relative to other individuals, as manifested in the differential deference individuals enjoy in the eyes of others (Piazza \& Castelluci, 2014). Talent status can thus be understood as a symbolic resource, characterized by what social exchange theory calls 'particularism' - meaning that the value of the resource depends specifically on who grants it (cf. a person's mother believing he or she is a talent has a different impact than one's manager conveying this message; Flynn, 2005). The incongruence between deserved and formal talent status, then, is more logically related to theories and measures of perceived organizational justice (Gelens et al., 2014).

As for future research, the identification of talents with the management function prior to their formal inclusion in it constitutes a promising topic. Our study shows that management identification represents a meaningful construct in its own right, and that it relates both to outcomes at the same level (supervisor-oriented OCB) and higher-order levels (organizationoriented OCB and turnover intention). Therefore, we call for more studies on its dynamics in talent management since, as pointed out by Hekman, van Knippenberg, and Pratt (2016), identification determines where one looks for behavioral and attitudinal guidance. Related to this point are the urgent calls for more research on the role of (line) management in talent 
management. In their systematic review of empirical studies, Gallardo-Gallardo and Thunnissen (2016) concluded that the "perception, role, and impact of the line manager [in talent management] is one of the most urgent research gaps" (p. 49). King (2016), as well, pleaded for more studies integrating the supervisor level both theoretically and empirically. It is, for instance, assumed that employees' perceptions of their organizations' talent management practices are almost entirely channeled through the behavior and messages of their line managers.

Another point for further research is the separation — both theoretically and empirically — of the effects of talent status and (specific) talent management practices on employees. To date, there has not yet been a study that was able to separate the two, or even a study that measured both simultaneously (Gallardo-Gallardo \& Thunnissen, 2016). That is, existing research on talent management has examined either the effects of TM practices (on a general employee population, without having information about talent status) or the effects of talent status (without having information about which practices were associated with the status). In the present study, as well, only talent status was examined, since our case organization had not implemented tangible practices specifically for 'talents'. This implies that the effects we found were largely caused by the symbolic nature of talent status (Cropanzano \& Mitchell, 2005). Interestingly, in their review paper De Boeck et al. (2018) proposed that social exchange theory is likely the better-fitting theory for understanding the effects of TM practices on employees, since practices represent 'tangible' resources that are exchanged, while social identity is like the better theory for explaining the (symbolic) effects of talent status. If future studies would be able to separate both variables, significant progress could be made in our understanding of the effects of TM on employees - for instance by contrasting the effects of talent status without specific practices associated with them, with the effects of specific practices without explicit communication about talent status, with the 
effects of status that is coupled to specific practices. This could be done by collecting data in a set of organizations with a different approach, or through experimental methods such as scenario (also called vignette or factorial survey) studies (Dries, 2013).

A different, but related research question for future studies on the social identities of employees identified as talents is the extent to which they identify with each other, as well as with the abstract notion of 'talent'. The former might lead to the emergence of faultlines in work groups, between talents and non-talents, where talents engage in more knowledge sharing and cooperation with other talents (Brewer \& Gardner, 1996). The opposite effect is also conceivable - that talents would become more competitive towards other talents, in an attempt to safeguard their newly acquired status (Dries \& Pepermans, 2007). We also believe that the talent label in and of itself can contribute to a so-called 'talent identity'. Labeling theory states that labels tend to mark boundaries between insiders and outsiders, thereby helping crystallize social identities. Most research on the identity effects of labels has focused on negative labels (i.e., autist, juvenile delinquent) and their harmful self-fulfilling effects (Ashforth \& Humphrey, 1995). Applied to the talent topic, future research could look at the potential motivating effects of the (highly positive) 'talent' label (cf. self-fulfilling prophecies, Pygmalion effects; Dries, 2013), but also undesirable side effects such as increased performance anxiety or imposter syndrome (Meyers et al., 2017).

Further research should also look deeper into the effects of TM on employees not identified as talents (Swailes \& Blackburn, 2016). As is the case in many other studies, we found a positive relationship between talent status and our outcome variables, but it is less clear whether this also implies a negative relationship between 'non-talent status' and employee outcomes (De Boeck et al., 2018). Looking at the means in Table 1 it appears that although there is a significant difference between both groups, we cannot state that nontalents score 'negatively' on any of the outcome variables. This issue is further compounded 
by the fact that non-talents are often less aware of their (lack of) status than talents are (Dries, 2013). In addition, it may be the case that other outcome variables - such as feelings of unfairness or work alienation — are more relevant for capturing reactions of non-talents (Meyers et al., 2017).

Finally, future research should look into moderators of the relationship between talent status and management identification. One potential moderator is the degree of TM transparency, as this influences both the salience of talent status for 'talents', and the extent to which 'non-talents' are aware of the differential treatment (Sonnenberg et al., 2014;

Ehrnrooth et al., 2018). Transparency is also related to other potential moderators proposed in the literature, such as perceived procedural justice (Gelens et al., 2014) and HR attributions linked to trust in management (e.g., whether TM is perceived as a commitment or a control mechanism; cf. De Boeck et al., 2018).

\section{Conclusion}

Our study is one of the first to adopt a social identity perspective to explain employee reactions to talent management, and to test how multiple identification foci might help us understand the dynamics of talent management. It demonstrates that talent management affects more than just a single facet of identity, thus responding to calls for more research on employees' multifaceted social identities (Horstmeier et al., 2017; Ramarajan, 2014).

Although organizational identification is by far the most studied 'focus' of identification, our findings imply that the social identity mechanisms triggered by talent management warrant a more nuanced understanding. The fact that talent status relates not only to identification with the organization, but also with management, indicates that talent management practices carry within them rich information about the symbolic meaning of talent status and its relationship to group belongings at work (De Boeck et al., 2018). We hope that these findings will inspire 


\section{TALENT STATUS AS SOCIAL IDENTITY -- 28}

other researchers to build on social identity theory to enhance understanding of the effects talent status on employees. 


\section{References}

Ashforth, B. E., Harrison, S. H., \& Corley, K. G. (2008). Identification in organizations: An examination of four fundamental questions. Journal of Management, 34(3), 325-374. doi:10.1177/0149206308316059

Ashforth, B. E., \& Humphrey, R. H. (1995). Labeling processes in the organization. Research in Organizational Behavior, 17, 413-461.

Ashforth, B. E., \& Johnson, S. A. (2001). Which hat to wear? The relative salience of multiple identities in organizational contexts. In M. A. Hogg \& D. J. Terry (Eds.), Social identity processes in organizational contexts (pp. 31-48). New York: Taylor \& Francis Group.

Bartels, J., Pruyn, A., De Jong, M., \& Joustra, I. (2007). Multiple organizational identification levels and the impact of perceived external prestige and communication climate. Journal of Organizational Behavior, 28(2), 173-190.

Björkman, I., Ehrnrooth, M., Mäkelä, K., Smale, A., \& Sumelius, J. (2013). Talent or not? Employee reactions to talent identification. Human Resource Management, 52(2), 195-214. doi:10.1002/hrm

Bollen, K. A. (1989). Structural equations with latent variables. New York: Wiley.

Brewer, M. B., \& Gardner, W. (1996). Who is this" We"? Levels of collective identity and self representations. Journal of Personality and Social Psychology, 71(1), 83-93.

Brislin, R. W. (1986). The wording and translation of research instruments. In W. J. Lonner \& J. W. Berry (Eds.), Field methods in cross-cultural research (pp. 137-164). Beverly Hills, CA: SAGE Publications.

Chami-Malaeb, R., \& Garavan, T. (2013). Talent and leadership development practices as drivers of intention to stay in Lebanese organisations: The mediating role of affective 
commitment. The International Journal of Human Resource Management, 24(21), 4046-4062.

Cole, M. S., \& Bruch, H. (2006). Organizational identity strength, identification, and commitment and their relationships to turnover intention: Does organizational hierarchy matter? Journal of Organizational Behavior, 27(5), 585-605. doi:10.1002/job.378

Collings, D. G. (2015). The contribution of talent management to organization success. In Kraiger, Passmore, dos Santos, \& Malvezzi (Eds.), The Wiley Blackwell handbook of the psychology of training, development, and performance improvement (pp. 247260). Chichester, UK: Wiley Blackwell.

Collings, D., \& Mellahi, K. (2009). Strategic talent management: A review and research agenda. Human Resource Management Review, 19(4), 304-313. doi:10.1016/j.hrmr.2009.04.001

Collings, D., Scullion, H., \& Caligiuri, P. M. (2010). Global talent management: Routledge. Cropanzano, R., \& Mitchell, M. S. (2005). Social exchange theory: An interdisciplinary review. Journal of management, 31(6), 874-900.

De Boeck, G., Meyers, M. C., \& Dries, N. (2018). Employee reactions to talent management: Assumptions versus evidence. Journal of Organizational Behavior, 39(2), 199-213.

Dries, N. (2013). The psychology of talent management: A review and research agenda. Human Resource Management Review, 23(4), 272-285. doi:10.1016/j.hrmr.2013.05.001

Dries, N., Forrier, A., De Vos, A., \& Pepermans, R. (2014). Self-perceived employability, organization-rated potential, and the psychological contract. Journal of Managerial Psychology, 29(5), 565-581. 
Dries, N., \& Pepermans, R. (2007). Using emotional intelligence to identify high potential: A metacompetency perspective. Leadership and Organization Development Journal, 28(8), 749-770.

Ehrnrooth, M., Björkman, I., Mäkelä, K., Smale, A., Sumelius, J., \& Taimitarha, S. (2018). Talent responses to talent status awareness-Not a question of simple reciprocation. Human Resource Management Journal, 28(3), 443-461.

Ellemers, N., \& Rink, F. (2005). Identity in work groups: The beneficial and detrimental consequences of multiple identities and group norms for collaboration and group performance. In S. R. Thye \& E. J. Lawler (Eds.), Social identification in groups (pp. 1-41). Bingley, UK: Emerald Group Publishing Limited.

Flynn, F. J. (2005). Identity orientations and forms of social exchange in organizations. Academy of Management Review, 30(4), 737-750.

Fuller, J. B., Hester, K., Barnett, T., Frey, L., Relyea, C., \& Beu, D. (2006). Perceived external prestige and internal respect: New insights into the organizational identification process. Human Relations, 59(6), 815-846.

Gallardo-Gallardo, E., \& Thunnissen, M. (2016). Standing on the shoulders of giants? A critical review of empirical talent management research. Employee Relations, 38(1), 31-56. doi:10.1108/ER-10-2015-0194

Gelens, J., Dries, N., Hofmans, J., \& Pepermans, R. (2015). Affective commitment of employees designated as talent: Signalling perceived organisational support. European Journal of International Management, 9(1), 9-27.

Gelens, J., Hofmans, J., Dries, N., \& Pepermans, R. (2014). Talent management and organisational justice: Employee reactions to high potential identification. Human Resource Management Journal, 24(2), 159-175. doi:10.1111/1748-8583.12029 
Hayes, A. F. (2018). Introduction to mediation, moderation, and conditional process analysis: A regression-based approach (2nd edition. ed.). New York: Guilford Publications.

Hekman, D. R., van Knippenberg, D., \& Pratt, M. G. (2016). Channeling identification: How perceived regulatory focus moderates the influence of organizational and professional identification on professional employees' diagnosis and treatment behaviors. Human Relations, 69(3), 753-780. doi:10.1177/0018726715599240

Horstmeier, C. A. L., Boer, D., Homan, A. C., \& Voelpel, S. C. (2017). The differential effects of transformational leadership on multiple identifications at work: A metaanalytic model. British Journal of Management, 28(2), 280-298. doi:10.1111/14678551.12160

Ibarra, H. (2005). Identity transitions: Possible selves, liminality and the dynamics of career change (No. 2005/51). Fontainebleu Cedex, France: Insead.

Khatri, N., Fern, C. T., \& Budhwar, P. (2001). Explaining employee turnover in an Asian context. Human Resource Management Journal, 11(1), 54-74. doi:10.1111/j.17488583.2001.tb00032.x

Khoreva, V., \& van Zalk, M. (2016). Antecedents of work engagement among high potential employees. Career Development International, 21(5), 459-479. doi:10.1108/JHOM09-2016-0165

King, K. A. (2016). The talent deal and journey: understanding the employee response to talent identification over time. Employee Relations, 38(1), 94-111.

Kuvaas, B., \& Dysvik, A. (2009). Perceived investment in employee development, intrinsic motivation and work performance. Human Resource Management Journal, 19(3), 217-236. doi:10.1111/j.1748-8583.2009.00103.x 
Lee, C. H., \& Bruvold, N. T. (2003). Creating value for employees: Investment in employee development. International Journal of Human Resource Management, 14(6), 9811000. doi:10.1080/0958519032000106173

Lee, E.-S., Park, T.-Y., \& Koo, B. (2015). Identifying organizational identification as a basis for attitudes and behaviors: A meta-analytic review. Psychological Bulletin, 141(5), 1049-1080. doi:10.1037/bul0000012

Lee, K., \& Allen, N. J. (2002). Organizational citizenship behavior and workplace deviance: The role of affect and cognitions. Journal of Applied Psychology, 87(1), 131-142. doi:10.1037/0021-9010.87.1.131

Mael, F., \& Ashforth, B. E. (1992). Alumni and their alma mater: A partial test of the reformulated model of organizational identification. Journal of Organizational Behavior, 13(2), 103-123.

Marique, G., \& Stinglhamber, F. (2011). Identification to proximal targets and affective organizational commitment: The mediating role of organizational identification. Journal of Personnel Psychology, 10(3), 107-117. doi:10.1027/1866-5888/a000040

McDonnell, A., Collings, D. G., Mellahi, K., \& Schuler, R. (2017). Talent management: A systematic review and future prospects. European Journal of International Management, 11(1), 86-128.

MacKinnon, D. P., Krull, J. L., \& Lockwood, C. M. (2000). Equivalence of the mediation, confounding and suppression effect. Prevention Science, 1(4), 173-181.

Meyers, M. C., de Boeck, G., \& Dries, N. (2017). Talent or not: Employee reactions to talent designations. In D. G. Collings, K. Mellahi, \& W. F. Cascio (Eds.), Oxford handbook of talent management (pp. 169-192). Oxford, UK: Oxford University Press. 
Meyers, M. C., \& van Woerkom, M. (2014). The influence of underlying philosophies on talent management: Theory, implications for practice and research agenda. Journal of World Business, 49(2), 192-203.

Michaels, E., Handfield-Jones, H., \& Axelrod, B. (2001). The war for talent. Boston, MA: Harvard Business School Press.

Millward, L. J., \& Haslam, S. A. (2013). Who are we made to think we are? Contextual variation in organizational, workgroup and career foci of identification. Journal of Occupational and Organizational Psychology, 86(1), 50-66. doi:10.1111/j.20448325.2012.02065.x

Organ, D. (1988). Ocb: The good soldier syndrome. Lexington, MA: Lexington Books.

Paré, G., \& Tremblay, M. (2007). The influence of high-involvement human resources practices, procedural justice, organizational commitment, and citizenship behaviors on information technology professionals' turnover intentions. Group and Organization Management, 32(3), 326-357. doi:10.1177/1059601106286875

Podsakoff, P. M., MacKenzie, S. B., Lee, J.-Y., \& Podsakoff, N. P. (2003). Common method biases in behavioral research: A critical review of the literature and recommended remedies. Journal of Applied Psychology, 88(5), 879-903. doi:10.1037/00219010.88 .5 .879

Preacher, K. (2015). Advances in mediation analysis: A survey and synthesis of new developments. Annual Review of Psychology, 66(1), 825-852.

Ramarajan, L. (2014). Past, present and future research on multiple identities: Toward an intrapersonal network approach. Academy of Management Annals, 8(1), 589-659. doi:10.1080/19416520.2014.912379 
Restubog, S. L. D., Hornsey, M. J., Bordia, P., \& Esposo, S. R. (2008). Effects of psychological contract breach on organizational citizenship behaviour: Insights from the group value model. Journal of Management Studies, 45(8), 1377-1400.

Riketta, M. (2005). Organizational identification: A meta-analysis. Journal of Vocational Behavior, 66(2), 358-384.

Riketta, M., \& Van Dick, R. (2005). Foci of attachment in organizations: A meta-analytic comparison of the strength and correlates of workgroup versus organizational identification and commitment. Journal of Vocational Behavior, 67(3), 490-510.

Rucker, D. D., Preacher, K. J., Tormala, Z. L., \& Petty, R. E. (2011). Mediation analysis in social psychology: Current practices and new recommendations. Social and Personality Psychology Compass, 5(6), 359-371. doi:doi:10.1111/j.17519004.2011.00355.x

Rupp, D. E., \& Cropanzano, R. (2002). The mediating effects of social exchange relationships in predicting workplace outcomes from multifoci organizational justice. Organizational Behavior and Human Decision Processes, 89, 925-946.

Silzer, R., \& Church, A. H. (2010). Identifying and assessing high-potential talent. Strategydriven Talent Management: A leadership Imperative, 28, 213-280.

Sonnenberg, M., van Zijderveld, V., \& Brinks, M. (2014). The role of talent-perception incongruence in effective talent management. Journal of World Business, 49(2), 272280.

Sousa, F. H., \& Vala, J. (2002). Relational justice in organizations: The group-value model and support for change. Social Justice Research, 15(2), 99-121.

Stets, J. E., \& Burke, P. J. (2003). Asociological approach to self and identity. In M. R. Leary \& J. P. Tangney (Eds.), Handbook of self and identity (pp. 128-152). New York: Guilford. 
Sumelius, J., Smale, A., \& Yamao, S. (2020). Mixed signals: employee reactions to talent status communication amidst strategic ambiguity. The International Journal of Human Resource Management, 31(4), 511-538.

Swailes, S., \& Blackburn, M. (2016). Employee reactions to talent pool membership. Employee Relations, 38(1), 112-128. doi:10.1108/ER-02-2015-0030

Swailes, S., Downs, Y., \& Orr, K. (2014). Conceptualising inclusive talent management: Potential, possibilities and practicalities. Human Resource Development International, $17(5), 529-544$.

Tajfel, H., \& Turner, J. C. (1979). An integrative theory of inter-group conflict. In W. G. Austin \& S. Worchel (Eds.), The social psychology of inter-group relations (pp. 3347). Monterey, CA: Brooks/Cole.

Tansley, C., \& Tietze, S. (2013). Rites of passage through talent management progression stages: An identity work perspective. International Journal of Human Resource Management, 24(9), 37-41. doi:10.1080/09585192.2013.777542

Tett, R. P., \& Meyer, J. P. (1993). Job satisfaction, organizational commitment, turnover intention, and turnover: Path analyses based on meta-analytic findings. Personnel Psychology, 46(2), 259-293.

Thunnissen, M., \& Buttiens, D. (2017). Talent management in public sector organizations: A study on the impact of contextual factors on the TM approach in Flemish and Dutch public sector organizations. Public Personnel Management, 46(4), 391-418.

Van Dick, R., Grojean, M. W., Christ, O., \& Wieseke, J. (2006). Identity and the extra mile: Relationships between organizational identification and organizational citizenship behaviour. British Journal of Management, 17(4), 283-301. doi:10.1111/j.14678551.2006.00520.x 
van Dick, R., Wagner, U., Stellmacher, J., \& Christ, O. (2004). The utility of a broader conceptualization of organizational identification: Which aspects really matter? Journal of Occupational and Organizational Psychology, 77(2), 171-191. doi:10.1348/096317904774202135

Van Knippenberg, D., \& Hogg, M. A. (2018). Social identifications in organizational behavior. In D. Ferris, R. Johnson \& C. Sedikides (Eds.) The self at work: Fundamental theory and research (pp. 72-90). New York, NY: Routledge Press. 


\section{Table 1}

Descriptive Statistics

\begin{tabular}{|c|c|c|c|c|c|c|c|c|c|c|c|}
\hline & $\begin{array}{c}\text { Non-talents } \\
(N=492)\end{array}$ & $\begin{array}{l}\text { Talents } \\
(N=105)\end{array}$ & $\begin{array}{c}\text { Total } \\
(N=597)\end{array}$ & & & & & & & & \\
\hline Variable & $M(S D)$ & $M(S D)$ & & 1 & 2 & 3 & 4 & 5 & 6 & 7 & 8 \\
\hline 1. Gender & $.19(.39)$ & $.12(.33)$ & $.18(.38)$ & -- & & & & & & & \\
\hline 2. Age & $46.95(11.09)$ & $47.68(7.10)$ & $47.07(10.50)$ & -0.02 & -- & & & & & & \\
\hline 3. Organizational tenure & $8.74(8.60)$ & $11.52(7.61)$ & $9.24(8.50)$ & -0.02 & $.51^{* *}$ & -- & & & & & \\
\hline 4. Management identification & $3.69(1.43)$ & $4.04(1.46)$ & $3.75(1.44)$ & $-.09^{*}$ & 0.04 & 0.01 & -- & & & & \\
\hline 5. Organizational identification & $5.61(.96)$ & $5.79(.87)$ & $5.64(.95)$ & $-.13^{* *}$ & 0.03 & $.09^{*}$ & $.46^{* *}$ & -- & & & \\
\hline 6. OCB-Organization & $5.36(.94)$ & $5.51(.89)$ & $5.39(.93)$ & $-.14^{* *}$ & 0.01 & $.09^{*}$ & $.43^{* *}$ & $.93^{* *}$ & -- & & \\
\hline 7. OCB-Supervisor & $4.21(1.67)$ & $4.98(1.57)$ & $4.35(1.68)$ & -0.03 & $.14^{* *}$ & $.09^{*}$ & $.43^{* *}$ & $.27^{* *}$ & $.26^{* *}$ & -- & \\
\hline 8. Turnover intention & $2.86(1.98)$ & $2.78(1.94)$ & $2.85(1.97)$ & 0.05 & -0.06 & $-.12^{* *}$ & $-.29^{* *}$ & $-.30^{* *}$ & $-.27^{* *}$ & $-.11^{* *}$ & -- \\
\hline 9. Talent status & -- & -- & $.18(.38)$ & -0.06 & 0.03 & $.12^{* *}$ & $.09^{*}$ & 0.07 & 0.06 & $.17^{* *}$ & -0.02 \\
\hline
\end{tabular}

Note. Gender: $0=$ Women, $1=$ Men; Talent status: $0=$ Non-talent, $1=$ Talent. 
Table 2

Direct and Total Effects of Talent Status on OCB-O, OCB-s, and Turnover Intention

\begin{tabular}{|c|c|c|c|c|c|c|}
\hline & \multicolumn{2}{|c|}{ OCB-Organization } & \multicolumn{2}{|c|}{ OCB-Supervisor } & \multicolumn{2}{|c|}{ Turnover intention } \\
\hline & Direct effect (SE) & Total effect (SE) & Direct effect (SE) & Total effect (SE) & Direct effect (SE) & Total effect (SE) \\
\hline Gender & $-.07(.05)$ & $-.26 * *(.08)$ & $.07(.14)$ & $-.11(.16)$ & $.05(.21)$ & $.29(.22)$ \\
\hline Age & $.00(.00)$ & $.00(.00)$ & $.02 * *(.01)$ & $.02 * *(.01)$ & $.00(.01)$ & $-.01(.01)$ \\
\hline Tenure & $.01 * *(.00)$ & $.01 * *(.00)$ & $.00(.01)$ & $.00(.01)$ & $-.03 * *(.01)$ & $-.04 * *(.01)$ \\
\hline Talent status & $.10 \dagger(.05)$ & $.23 * *(.08)$ & $.38 * *(.14)$ & $.57 * *(.16)$ & $.24(.21)$ & $.06(.22)$ \\
\hline Management identification & $.14 * *(.03)$ & & $.74 * *(.08)$ & & $-.41 * *(.12)$ & \\
\hline Organizational identification & $.64 * *(.04)$ & & $.07(.09)$ & & $-.56 * *(.14)$ & \\
\hline$R^{2}$ & $.58 * *$ & $.05^{* *}$ & $.25^{* *}$ & $.04 * *$ & $.13 * *$ & $.03 * *$ \\
\hline
\end{tabular}

Note. Unstandardized regression coefficients; ${ }^{* *} \mathrm{p}<.01,{ }^{*} \mathrm{p}<.05, \dagger \mathrm{p}<.10$. 


\section{Table 3}

Indirect Relationships for Parallel vs. Serial Mediation Model

\begin{tabular}{|c|c|c|c|c|c|c|}
\hline & \multicolumn{3}{|c|}{ Parallel mediation model } & \multicolumn{3}{|c|}{ Serial mediation model } \\
\hline & OCB-Organization & OCB-Supervisor & Turnover intention & OCB-Organization & OCB-Supervisor & Turnover intention \\
\hline $\begin{array}{l}\text { Talent status }=> \\
\text { Management } \\
\text { identification }=> \\
\text { DVs }\left(a_{1} b_{1}\right)\end{array}$ & $\begin{array}{l}.04 \\
{[.009-.067]}\end{array}$ & $\begin{array}{l}.19 \\
{[.051-.333]}\end{array}$ & $\begin{array}{l}-.10 \\
{[-.220--.020]}\end{array}$ & $\begin{array}{l}.04 \\
{[.008-.068]}\end{array}$ & $\begin{array}{l}.19 \\
{[.046-.336]}\end{array}$ & $\begin{array}{l}-.10 \\
{[-.222--.020]}\end{array}$ \\
\hline $\begin{array}{l}\text { Talent Status }=> \\
\text { Organizational } \\
\text { identification }=> \\
\text { DVs }\left(a_{2} b_{2}\right)\end{array}$ & $\begin{array}{l}.09 \\
{[-.009-.185]}\end{array}$ & $\begin{array}{l}.01 \\
{[-.019-.048]}\end{array}$ & $\begin{array}{l}-.08 \\
{[-.174-.005]}\end{array}$ & $\begin{array}{l}.00 \\
{[-.066-.084]}\end{array}$ & $\begin{array}{l}.00 \\
{[-.015-.015]}\end{array}$ & $\begin{array}{l}-.01 \\
{[-.076-.063]}\end{array}$ \\
\hline $\begin{array}{l}\text { Talent status }=> \\
\text { Management } \\
\text { identification }=> \\
\text { Organizational } \\
\text { identification => } \\
\text { DVs }\left(\mathrm{a}_{1} \mathrm{~d}_{21} \mathrm{~b}_{2}\right)\end{array}$ & & & & $\begin{array}{l}.08 \\
{[.022-.143]}\end{array}$ & $\begin{array}{l}.01 \\
{[-.015-.039]}\end{array}$ & $\begin{array}{l}-.07 \\
{[-.139--.014]}\end{array}$ \\
\hline
\end{tabular}

Note. Unstandardized regression coefficients; 95\% CI range is reported between brackets. Statistically significant results are bolded.

\section{Table 4}

Direct, Indirect and Total Effects of Talent Status on OCB-O, OCB-s, and Turnover Intention (Parallel vs. Serial Mediation Model)

\begin{tabular}{lcccc}
\hline & Total direct effect & Total indirect effect - Parallel & Total indirect effect - Serial & Total effect \\
\hline OCB-Organization & $.10[-.002-.203]$ & $\mathbf{. 1 2}[\mathbf{. 0 0 9}-\mathbf{. 2 3 6}]$ & $\mathbf{. 1 2}[\mathbf{. 0 1 2}-\mathbf{. 2 3 5}]$ & $\mathbf{. 2 3}[\mathbf{. 0 7 2}-\mathbf{. 3 7 8}]$ \\
OCB-Supervisor & $\mathbf{. 3 8}[\mathbf{. 1 0 4}-\mathbf{. 6 5 2}]$ & $\mathbf{. 2 0}[\mathbf{. 0 5 0}-\mathbf{. 3 5 0}]$ & $\mathbf{. 2 0}[\mathbf{. 0 5 0}-\mathbf{. 3 4 5}]$ & $\mathbf{. 5 7}[. \mathbf{2 6 6}-\mathbf{. 8 8 1}]$ \\
Turnover intention & $.24[-.176-.664]$ & $\mathbf{- . 1 8}[-. \mathbf{3 3 0}-\mathbf{- . 0 3 6}]$ & $\mathbf{- . 1 8}[-. \mathbf{3 3 3}-\mathbf{- . 0 3 6}]$ & $.06[-.378-.504]$
\end{tabular}

Note. Unstandardized regression coefficients; $95 \%$ CI range is reported between brackets. Total direct effect represents the path c'. Total indirect effect represents the paths $a_{1} b_{1}+a_{2} b_{2}$ (parallel model) $+a_{1} d_{21} b_{2}$ (serial model). Total effect represents the paths $c^{\prime}+a_{1} b_{1}+a_{2} b_{2}+a_{1} d_{21} b_{2}$. Statistical significance results are bolded. 


\section{Figure 1}

Direct and Indirect Effects of Talent Status on $O C B-O, O C B-s$, and Turnover Intention (Parallel vs. Serial Mediation Model)

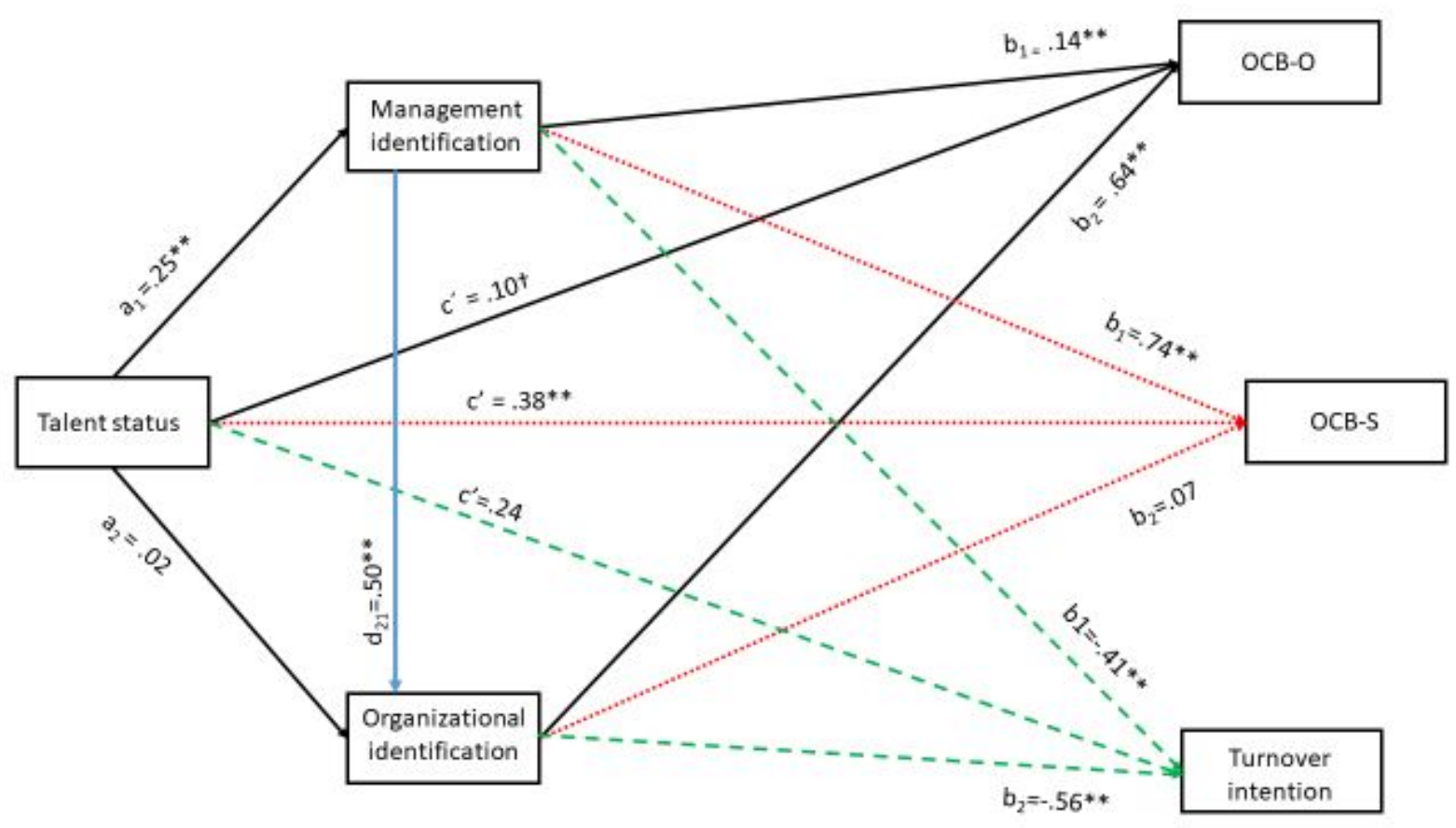

Note. The coefficient $\mathrm{d}_{21}$ is the directional relationship between management identification and organizational identification and exists only in the serial mediation model. 